\title{
Przemystaw Śleszyński
}

Instytut Geografii i Przestrzennego Zagospodarowania PAN

psleszyn@twarda.pan.pl

\section{Aktualne i spodziewane procesy demograficzne w gminie Pleszew i ich znaczenie dla polityki przestrzennej}

\begin{abstract}
Zarys treści: Opracowanie jest skrótem ekspertyzy, wykonanej dla władz samorządowych Pleszewa. Jej celem była m.in. wariantowa prognoza ludnościowa do 2050 r. w oparciu o alternatywne sposoby szacowania liczby ludności, sporządzona dla potrzeb planowania przestrzennego i rozwoju miasta i gminy. W projekcjach zastosowano metodę kohortowo-składnikową i opracowano dwie projekcje na podstawie dwóch scenariuszy rozwoju gminy. Następnie wyniki skonfrontowano $z$ bilansem terenów pod różne funkcje w studium uwarunkowań i kierunków zagospodarowania przestrzennego, wykazując pewną nadwyżkę terenów inwestycyjnych. Oprócz tego wyniki mogą być traktowane jako przyczynek do rozpoznania procesów demograficznych i ich uwarunkowań $w$ jednym $z$ miast pogranicznego zbioru małych i średnich ośrodków.
\end{abstract}

Słowa kluczowe: struktura demograficzna ludności, migracje wewnętrzne, prognoza demograficzna, planowanie przestrzenne, chłonność demograficzna, Pleszew

\section{Cele, założenia i zakres opracowania}

Głównym celem opracowania jest przedstawienie spodziewanych możliwości rozwoju gminy miejsko-wiejskiej Pleszew w kontekście zjawisk i procesów demograficznych, mających wpływ na planowanie i zagospodarowanie przestrzenne. Wiedza taka jest niezbędna przede wszystkim $z$ powodu prognozowania realnych potrzeb inwestycyjnych na terenach różnego typu, w tym pod budownictwo mieszkaniowe. Wśród ekspertów istnieje zgodność, że aby dobrze planować i gospodarować przestrzenią, konieczna jest rzetelna i wiarygodna diagnoza zachodzących procesów społeczno-gospodarczych (Fogel 2012, Parysek 2016). Istnieje szereg przykładów sporządzania lokalnych diagnoz i prognoz demograficznych, np. dla potrzeb strategii rozwoju miast i gmin (Zborowski 2001, Paradysz 2012, Górecka i in. 2016), planowania oświaty (Bąkowska i in. 2016) czy zagospodarowania przestrzennego (Śleszyński 2018). Aktualny pozostaje pogląd A. Jarczewskiego, byłego wiceprezydenta Gliwic, że sporządzane dla całego kraju 
„prognozy ludnościowe, nawet alarmistyczne, nie pomagają w podejmowaniu decyzji, bo nie są zaadresowane. Burmistrz, starosta czy marszałek nie wie, jak on, samorządowiec, może spożytkować sygnały demograficzne, które codziennie poprzez media doń docierają. Potrzebna jest metoda (...) dla samorządu" (Jarczewski 2015, s. 207).

Zakres opracowania obejmuje analizę podstawowych uwarunkowań endogenicznych i egzogenicznych, w tym demograficznych, głównie w latach 2005-2017, czyli po wejściu Polski do Unii Europejskiej. Główną częścią opracowania jest właściwa prognoza, a we wnioskach zawarto najważniejsze zalecenia dla polityki przestrzennej gminy, wynikające z opracowania.

\section{Źródła danych}

W analizie i prognozie procesów demograficznych kluczowa jest kwestia prawidłowej identyfikacji stanów i struktury ludności. W przypadku prognoz demograficznych w Polsce najczęstszym problemem jest złe oszacowanie stanów ludnościowych, które skutkuje dalej błędnym obliczeniem zdarzeń, takich jak zwłaszcza poziom urodzeń (Bijak i in. 2006). Wynika to $z$ faktu, że poziom migracji, opierający się na statystyce wymeldowań i zameldowań, jest zaniżony. Ponieważ wędrują najczęściej osoby młode, zakładające rodziny, największe błędy dotyczą poziomu urodzeń. Przeszacowane są regiony peryferyjne (odpływowe), a niedoszacowane najbardziej atrakcyjne aglomeracje (z Warszawą na czele) i strefy podmiejskie miast. Istnieje już stosunkowo obszerna literatura, wskazująca, że błędy w zakresie identyfikacji ludności sięgają około 5-15\% stanów w strefach podmiejskich oraz do $30 \% \mathrm{w}$ najbardziej odpływowych regionach, m.in. z powodu nierejestrowanej emigracji zagranicznej (Śleszyński 2011, Jończy 2014).

Biorąc pod uwagę powyższe uwarunkowania, w opracowaniu posłużono się kilkoma komplementarnymi źródłami informacyjnymi, takim jak:

a. dane z rejestracji bieżącej ludności (Bank Danych Lokalnych GUS), oparte na rejestrowanych zdarzeniach demograficznych;

b. międzygminne dane macierzowe o wymeldowaniach i zameldowaniach $z$ lat 1989-2015 (GUS);

c. dane o strukturze dokumentów planistycznych (studium uikzp, miejscowe plany zagospodarowania przestrzennego) pochodzące $z$ raportów IGiPZ PAN dla Ministerstwa Infrastruktury i Budownictwa, a pozyskiwane dla całego kraju według jednolitej metodologii GUS (badanie PZP-1);

d. dane o różnicach adresów zameldowania i korespondencyjnych mieszkańców według baz adresowych ZUS (Śleszyński 2011).

\section{Specyfika geograficzno-funkcjonalna gminy}

Procesy demograficzne w gminie Pleszew wynikają z dwóch głównych uwarunkowań: współczesnego położenia względem większych ośrodków miejskich oraz 
tradycji historyczno-osadniczej. W Wielkopolsce poświęcono temu zagadnieniu szereg badań, w których wskazuje się m.in. na polaryzację wewnętrzną regionu (Kołodziejczak 2007, Dolata 2009, Męczyński i in. 2010), słabość podstaw rozwojowych mniejszych miast poza aglomeracją poznańską przy pozostawaniu szeregu zwłaszcza mniejszych miast w stanie swoistego zawieszenia między dywergencją i konwergencją rozwojową (Hauke, Konecka-Szydłowska 2011), jak też stagnację obszaru (powiatu) pleszewskiego, względem np. obszaru kaliskiego (Dominiak, Konecka-Szydłowska 2014). Nowsze prace zwracają uwagę na takie kwestie, jak m.in. silne zmiany w zakresie bazy ekonomicznej, polegające na ujednolicaniu struktury funkcjonalnej miast wraz z tercjaryzacją ich gospodarki (Konecka-Szydłowska, Maćkowiak 2016), opóźnienia w „samotransformacji” województwa (Czyż, Perdał 2016) oraz problemy tzw. prężności (rezyliencji) miejskiej, czyli odporności na zakłócenia (Konecka-Szydłowska 2018).

Współczesne położenie Pleszewa między Poznaniem (ok. $80 \mathrm{~km}$ na północny zachód), Kaliszem (ok. 30 km na południowy wschód) i Ostrowem Wielkopolskimi (ok. $10 \mathrm{~km}$ na wschód) sprawia, że obszar pozostaje w strefie oddziaływania tych ośrodków. Przy tym według analiz Bula i Kaczmarka (2016) z uwagi na peryferyjne położenie jest to jeden z obszarów województwa słabiej powiązanych z Poznaniem. Według klasyfikacji Śleszyńskiego i Komornickiego (2016) gminę zaliczono do typu E (miasta - ośrodki wielofunkcyjne). Gmin tego typu wyróżniono we wspomnianej klasyfikacji 147 i należy je traktować jako ogniwo pośrednie między szczeblem subregionalnym (np. Kalisz, Ostrów Wielkopolski) a lokalnym (np. Chocz). Tym samym gminę, a zwłaszcza miasto Pleszew, można traktować jako ustabilizowany ośrodek miejski o wyraźnie zaznaczonych funkcjach wielofunkcyjnej obsługi i wykształconym zasięgu oddziaływania. Inne gminy-miasta tego typu w regionie to m.in. Jarocin i Krotoszyn, położone zresztą w niedużej odległości od Pleszewa.

Według często przywoływanej w literaturze ekspertyzy Męczyńskiego i in. (2010), Pleszew znalazł się w przeciętnej klasie rozwoju (w 3 spośród klas 1-5, wraz z Grodziskiem Wielkopolskim, Czarnkowem, Szamotułami, Międzychodem i Trzcianką). Z kolei według badań Churskiego (2012), Pleszew plasuje się w tej samej grupie miast o zbliżonych cechach poziomu rozwoju społeczno-gospodarczego, co następujące gminy województwa: Kłecko, Krzyż Wielkopolski, Nowe Miasto nad Wartą, Rogoźno, Trzemeszno (wg metody odległości taksonomicznej i metody elementarnego połączenia McQuitty’ego) oraz Krzyż Wielkopolski, Trzcianka i Ujście (wg metody przyrostu odległości taksonomicznej Daceya). Co ciekawe, wszystkie (poza Nowym Miastem nad Wartą) są podobnie jak Pleszew gminami miejsko-wiejskimi. Natomiast według typologii Sleszyńskiego (2017), miasto sklasyfikowano w grupie 122 średnich miast tracących funkcje jako „zagrożone marginalizacją". Jest to wynik polaryzacyjnego modelu rozwoju kraju i „wysysania” potencjałów rozwojowych przez największe ośrodki, w tym z tzw. wielkiej piątki (Warszawa, Trójmiasto, Poznań, Wrocław, Kraków). Przy tym słabo zdiagnozowany jest wpływ reformy administracyjnej na sytuację gospodarczą pobliskiego Kalisza, według poglądów Krysińskiego (2013) istnieją poważne bariery świadomościowe, związane z degradacją administracyjną miasta. 
Z punktu widzenia analizy procesów demograficznych duże znaczenie ma też historia społeczno-gospodarcza (Podemski, Przestalski 2015). Od końca XVIII do początku XX w. gmina leżała na wschodnich rubieżach zaboru pruskiego, blisko granicy z zaborem rosyjskim i Królestwem Polskim. Spowodowało to, że procesy urbanizacji nie rozwinęly się w takim stopniu, jak w innych częściach zachodniej Polski. Aktualnie urbanizacja statystyczna w powiecie pleszewskim wynosi zaledwie około $35 \%$, ale w samej gminie odsetek osób mieszkających w mieście jest wyższy (58\%).

\section{Stan i dynamika ludności w ostatniej dekadzie}

\section{Zmiany rejestrowanej liczby ludności}

W końcu 2017 r. w gminie było zameldowanych na stałe 30026 mieszkańców. Oznacza to słaby wzrost o 0,4\% w stosunku do 2007 r. Przy tym w pierwszym okresie (2007-2012) był jeszcze rejestrowany wzrost, ale po 2010 r. tendencje odwróciły się (ryc. 1).

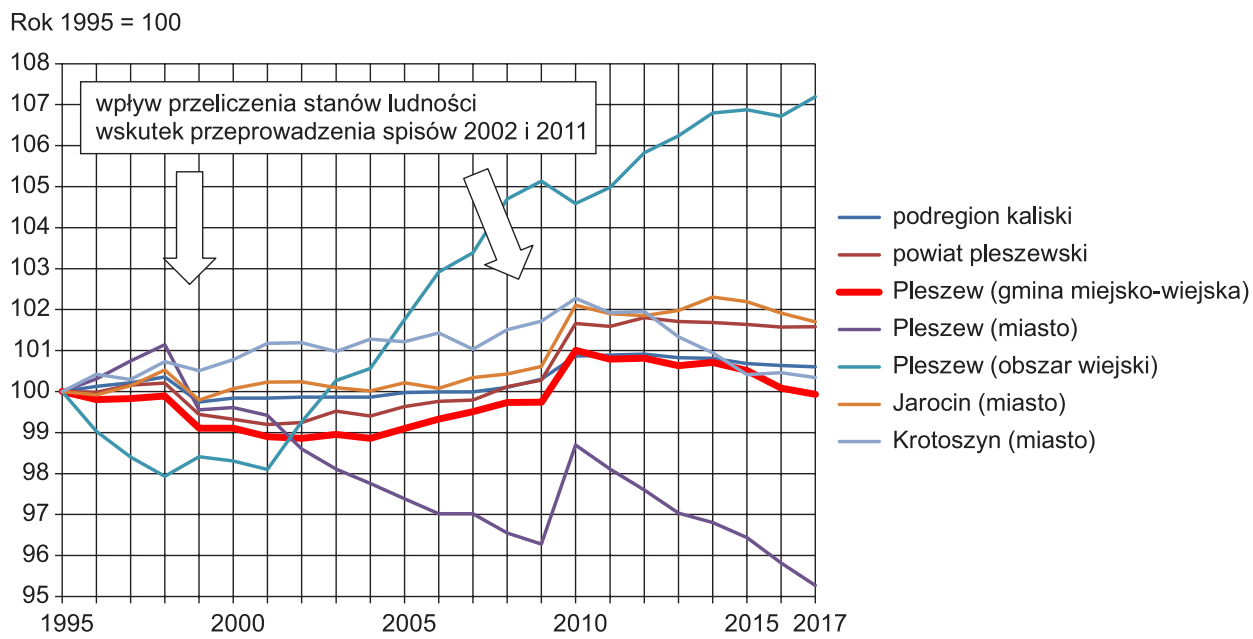

Ryc. 1. Dynamika rejestrowanej liczby ludności w gminie Pleszew na tle otoczenia (rok $1995=100)$ i ograniczenia ze strony źródeł danych Źródło: na podstawie danych BDL GUS.

Sytuacja była odmienna, jeśli chodzi o podział na miasto i obszar wiejski. W tym pierwszym tendencja jest wyraźnie spadkowa, z silniejszym wzrostem w 2010 r. wskutek przeliczenia wstecz przez GUS stanów ludnościowych w rezultacie przeprowadzenia spisu powszechnego 2011 (miasto - wzrost, obszar wiejski - spadek). Na tle innych miast (Jarocin, Krotoszyn) sytuacja była dość podobna.

Jeśli chodzi o obszar wiejski, w zasadzie w całym okresie notował on wzrost, co było wynikiem suburbanizacji Pleszewa. Zjawisko to, jeszcze na początku 
bieżącego stulecia ograniczone do największych polskich miast, od ponad dekady charakteryzuje coraz niższe szczeble hierarchiczne systemu osadniczego. Przy tym jednak tempo tego procesu było szybsze w okresie 2001-2010, a w ostatnich latach charakterystyczne jest coraz silniejsze wyhamowywanie. Oznacza to wyczerpywanie się zasobów migracyjnych oraz spadek populacji w wieku rozrodczym.

\section{Ruch naturalny}

W dekadzie 2008-2017 w gminie notowano od 150 do 212 małżeństw rocznie i wskaźnik ten w dłuższym okresie spada. Na tle pewnego wahania liczby ludności trend jest jednak wyraźniej malejący i wskazuje osłabienie wskaźnika względnego (liczba małżeństw na 1000 mieszkańców) o około 20\%. Przy tym w ostatnim badanym roku (2017) notowany jest wyraźny spadek liczby zawartych małżeństw $\mathrm{w}$ wartościach bezwzględnych do jednego $\mathrm{z}$ najniższych poziomów (142), a w wartościach względnych do 4,7 zdarzenia na 1000 mieszkańców.

$\mathrm{W}$ tym samym okresie liczba urodzeń żywych wahała się w granicach od 369 (2008 r.) do 265 (2013 r.), a w odniesieniu do liczby mieszkańców było to od 8,8 do 12,2 urodzenia na każde 1000 populacji. Jest to dość przeciętny poziom, o którym świadczy dodatkowe przeliczenie liczby urodzeń żywych na 1000 mieszkańców w wieku produkcyjnym mobilnym (19-39 lat). W gminie Pleszew wskaźnik ten wyniósł 25,9, co wśród wszystkich gmin w Polsce dało odległe 869 miejsce (1 miejsce w tym zestawieniu zajmuje kaszubska gmina Sierakowice ze wskaźnikiem w 2017 r. równym 46,8).

W przypadku zgonów notowano wartości od 255 do 331 i w długim okresie sytuacja jest tu dość stabilna (ok. 9-11 zdarzeń na 1000 populacji). Według ostatnich dostępnych danych za 2016 r. na każdy 1000 mieszkańców było to 11 zdarzeń. Natomiast wynikiem nadwyżki zgonów nad urodzeniami jest ujemne saldo ruchu naturalnego. Saldo to (ubytek naturalny) wykazuje od 2008 r. tendencję spadkową.

\section{Migracje rejestrowane}

W świetle rejestrowanych danych poziom migracji w ostatniej dekadzie wykazywał tendencję do zmniejszania się obrotów migracyjnych przy oscylowaniu salda nieco poniżej zera. W latach 2008-2017 odnotowano 2,5 tys. napływów i 2,9 tys. odpływów, a zatem saldo było ujemne (0,4 tys.). Tylko w kilku latach saldo było dodatnie, osiągając w rekordowych latach 1995 i 2007 około 50 zdarzeń. Nie oddaje to jednak $\mathrm{w}$ żaden sposób faktycznej mobilności, zwłaszcza międzynarodowej. Według ostatnich szczegółowych danych z NSP 2002 w mieście odnotowano aż 175 osób, przebywających 12 miesięcy i dłużej poza granicami kraju. Jednak biorąc pod uwagę wyniki specjalistycznych analiz, porównujących rejestrowaną według różnych źródeł mobilność zagraniczną (Śleszyński 2013), liczbę tę należy aktualnie uznać za dwu- lub nawet trzykrotnie wyższą.

Kierunki migracji zestawiono w tabeli 1 oraz na mapach (ryc. 2). Posłużono się danymi z macierzy migracyjnej GUS za lata 2011-2015. W strukturze ruchu 
Tabela 1. Podstawowe wskaźniki rejestrowanych przepływów migracyjnych do i z gminy Pleszew w latach 2011-2015 (pięć roczników).

\begin{tabular}{lrrrrrrrrrrr}
\hline \multirow{2}{*}{ Kierunek } & \multicolumn{2}{c}{ Obrót } & \multicolumn{2}{c}{ Napływ } & \multicolumn{2}{c}{ Odpływ } & Saldo & $\begin{array}{c}\text { Efektyw- } \\
\text { ność }\end{array}$ \\
\cline { 2 - 12 } & liczba & $\%$ & liczba & $\%$ & liczba & $\%$ & liczba & $\%$ & $\%$ \\
\hline Powiat pleszewski & 608 & 29,6 & 322 & 35,4 & 286 & 25,1 & 36 & $-15,6$ & 5,9 \\
Aglomeracja poznańska & 262 & 12,8 & 64 & 7,0 & 198 & 17,4 & -134 & 58,0 & $-51,1$ \\
Województwo wielkopolskie & 857 & 41,8 & 386 & 42,4 & 471 & 41,3 & -85 & 36,8 & $-9,9$ \\
Polska & 324 & 15,8 & 138 & 15,2 & 186 & 16,3 & -48 & 20,8 & $-14,8$ \\
\hline Ogółem & 2051 & 100,0 & 910 & 100,0 & 1141 & 100,0 & -231 & 100,0 & $-11,3$ \\
\hline
\end{tabular}

Źródło: na podstawie danych GUS.
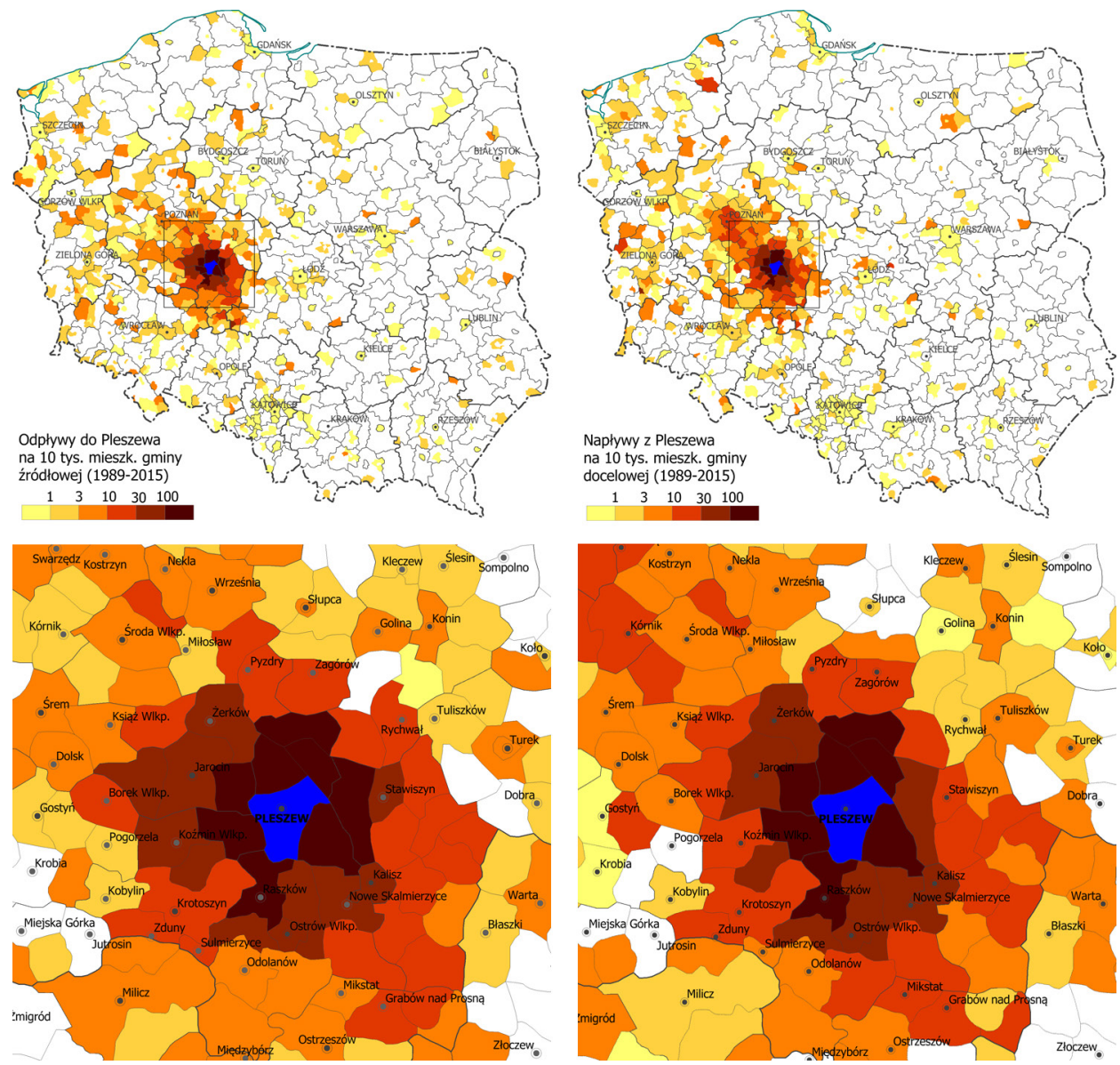

Ryc. 2. Kierunki rejestrowanych odpływów do gminy Pleszew w latach 1989-2015 (Polska)

Źródło: na podstawie danych GUS. 
wędrówkowego dominowało województwo wielkopolskie, na które przypadło po około $85 \%$ obrotu, mniej więcej tyle samo po stronie napływu i odpływu. Przy tym relatywnie więcej napływów pochodziło z powiatu pleszewskiego (35\%), a stosunkowo więcej odpływów - do aglomeracji poznańskiej (17\%). Tak więc z powiatem pleszewskim saldo było dodatnie, a z ośrodkiem poznańskim - ujemne. Ta prawidłowość po części jest pożądana, bowiem oznacza tendencję do koncentracji w gminie mieszkańców terenów wiejskich. Jednak równoczesne ujemne saldo z aglomeracją poznańską oznacza drenaż. Natomiast z pozostałymi częściami województwa bilans jest w zasadzie zrównoważony.

\section{Migracje nierejestrowane}

W warunkach polskich w wielu gminach w oszacowaniu faktycznej liczby mieszkańców niezwykle istotna jest rola migracji nierejestrowanych. Według badań porównawczych wyników spisu powszechnego 2002 i rejestracji bieżącej w gminie Pleszew stwierdzono jednak stosunkowo niewielkie różnice: na niekorzyść miasta, tj. przeszacowanie stanów ludności (o ok. 200 osób) oraz na korzyść obszaru wiejskiego (o ok. 50 osób). A zatem ogólny bilans wynoszący około -150 osób stanowi zaledwie $0,5 \%$ populacji gminy (w tym $1,1 \%$ populacji miasta). Również dane NSP 2002 wykazały, że z gminy Pleszew 175 osób przebywało poza granicami kraju „czasowo” powyżej 12 miesięcy (w praktyce ta „czasowość” oznacza, że zdecydowana większość osób przeniosła się na stałe). Przy tym wiadomo, że od spisu powszechnego 2002 problem nierejestrowanej emigracji w wartościach liczbowych potroił się. Ponadto stwierdzono, że w bazach ZUS dla województwa mazowieckiego w 2011 r. (jedyne dostępne dane, zob. Śleszyński 2011) występują tylko 23 niezgodności adresów zameldowania i korespondencji, w których figuruje Pleszew. W 11 przypadkach osoby były zameldowane w Pleszewie, a adres korespondencji podawały warszawski.

Gdyby zatem zsumować wszystkie dostępne dane, należałoby sądzić, że rzeczywista populacja miasta jest przeszacowana w stosunku do rejestracji bieżącej ludności o 500-600 osób, czyli niecałe 2\%. Jest to stosunkowo mała wartość, jednak z uwagi na fakt, że dotyczy ona szczególnie istotnej części populacji w wieku produkcyjnym mobilnym, najsilniej wpływającym na dzietność, powinna być uwzględniona w prognozie ludności.

\section{Przesłanki dla prognozy demograficznej}

\section{Uwarunkowania demograficzne}

Analiza demograficzna wykonana w poprzednim podrozdziale wyraźnie wskazuje na kilka grup czynników, decydujących o spodziewanym rozwoju ludnościowym gminy w perspektywie najbliższych dwóch-trzech dekad. Dotyczy to pewnej poprawy dzietności, stabilizacji strumieni migracyjnych (przy ujemnym saldzie) oraz bardzo szybkiego pogarszania się struktury wieku. 
Gdyby zakładać utrzymanie się makroekonomicznych i makrospołecznych warunków otoczenia (wzrost gospodarczy, kontynuacja polityki prorodzinnej), można przewidywać, że w perspektywie kolejnego pokolenia (ok. 2035 r.) poziom urodzeń nie będzie już tak wysoki i spadnie do około $65 \%$ stanu obserwowanego współcześnie (nawet przy założeniu trwałości w czasie polityki prorodzinnej). Wynika to $z$ faktu, że na terenie gminy populacja dzieci w wieku 0-4 lat ma właśnie taki mniej więcej udział w stosunku do kategorii osób w wieku 25-34 lata. Równocześnie dość wyraźnie zwiększy się poziom zgonów ze względu na przesuwanie się kolejnych roczników z powojennego wyżu blisko średniej oczekiwanej długości życia. Warto tu jednak podkreślić możliwości zwiększenia poziomu urodzeń wskutek ewentualnych zachęt gminy. Wówczas można byłoby się spodziewać spadku liczby urodzeń do poziomu 80-90\% stanu obserwowanego obecnie, co byłoby wariantem bardzo optymistycznym. W sumie daje to przesłanki do formułowania dwóch wariantów z punktu widzenia ruchu naturalnego: minimalnego i maksymalnego.

Drugie podstawowe znaczenie dla prognozy demograficznej gminy ma spodziewany napływ i odpływ migracyjny. Tutaj sytuacja jest dość jednoznaczna, bowiem gminę w całym okresie po 1989 r. charakteryzowało ujemne saldo ruchu wędrówkowego, a oprócz tego kilkaset osób przebywa poza granicami kraju „czasowo”. Zatem nawet w wariancie maksymalnym stopa napływu nie mogłaby być szczególnie wysoka, choć, jak się wydaje, mogłaby przewyższać odpływ.

Istotnym uwarunkowaniem ruchu wędrówkowego ludności w przyszłości będzie spadek zasobów migracyjnych. Według pospisowej prognozy GUS, w latach 2015-2050 liczba osób w wieku produkcyjnym mobilnym w podregionie kaliskim (głównej potencjalnej zlewni Pleszewa) zmniejszy się z 265 do 166 tys., a więc osiągnie zaledwie nieco ponad $60 \%$ obecnego stanu. Będzie się to dodatkowo odbywało w warunkach coraz silniejszej konkurencji o pracowników w efekcie pogłębiania się luki podażowej na rynku pracy. W sumie perspektywy migracyjne dla Pleszewa są niekorzystne.

\section{Uwarunkowania osadnicze}

Uwarunkowania osadnicze można rozpatrywać na dwa sposoby. Po pierwsze, są to kwestie dotyczące sieci miast i wsi oraz ich powiązań. Drugi aspekt ma wymiar lokalny i odnosi się do struktury morfologicznej zabudowy, m.in. mieszkaniowej, także w kontekście jej zwartości i rozpraszania.

Sytuacja Pleszewa pod względem obydwu uwarunkowań osadniczych jest dość korzystna z dwóch powodów. Po pierwsze, miasto ma dość zwartą strukturę osadniczą i silniejsze procesy rozgęszczania nie występują. Istnieją też pewne rezerwy pod zabudowę. Po drugie, miasto leży przy ważnej regionalnie linii kolejowej z Poznania w kierunku Katowic (linia nr 272 relacji Poznań Główny-Pleszew-Ostrów Wielkopolski-Kępno-Kluczbork). Oznacza to korzystne położenie z punktu widzenia możliwości kształtowania dojazdów do pracy. 
Jeśli chodzi o jednostki wiejskie, to mają one również dość korzystną strukturę osadniczą. Według analiz wykonanych na potrzeby „Raportu o kosztach chaosu przestrzennego w Polsce" (Kowalewski i in. 2018), w gminie:

- na 1 mieszkańca przypada około 7 m wodociągów, co w skali kraju jest bardzo dobrym wynikiem z uwagi na fakt, że jest to także gmina miejsko-wiejska (przykładowo w rozproszonych gminach Warmii, Mazur i Podlasia wskaźnik ten osiąga nawet powyżej $30 \mathrm{~m} /$ mieszkańca);

- wskaźnik minimalnego drzewa rozpinającego (MDR, najkrótsza ścieżka) obliczonego dla punktów adresowych w przeliczeniu na osobę wyniósł 8,7 m;

- według analiz Gibasa i Heffnera (2018), rozproszenie zabudowy będzie generować nadmierne koszty uzbrojenia i utrzymania infrastruktury w wysokości 910 tys. zł, czyli 30 zł na 1 mieszkańca. Jest to na tle kraju stosunkowo niską wartością (mediana dla wszystkich gmin w cytowanych badaniach wyniosła 290 zł, a łączne koszty - 35,5 mld zł), świadczącą o relatywnie niewielkim, na tle kraju, rozproszeniu zabudowy.

Ponadto poziom urbanizacji statystycznej w powiecie jest stosunkowo niewielki (35\%) i z tego powodu można domniemywać o pewnym potencjale migracyjnym wskutek „niedokończonej” urbanizacji. W sumie uwarunkowania osadnicze dla rozwoju gminy, a tym samym rozwoju demograficznego są korzystne. Brak tendencji do powszechnego w Polsce rozpraszania zabudowy skutkuje wyższą efektywnością sieci i urządzeń infrastruktury, co będzie miało duże, korzystne znaczenie wobec spodziewanego postarzania struktury wieku.

\section{Uwarunkowania gospodarcze}

Położenie i specyfika funkcjonalna gminy warunkuje rozwój gospodarki i przedsiębiorczości, a te wpływają na procesy demograficzne $\mathrm{w}$ przyszłości. $\mathrm{Z}$ powodu braków w statystyce publicznej nie jest możliwe nawet szczątkowe oszacowanie podstawowej zmiennej społeczno-gospodarczej, jaką jest liczba miejsc pracy $\mathrm{w}$ gminie. Ostatnie w miarę wiarygodne dane pochodzą ze spisu powszechnego w 2002 r. i dotyczą liczby osób zameldowanych w gminie i pracujących (10,4 tys.). $\mathrm{Z}$ tego 2,0 tys. (20\%) pracowało formalnie w rolnictwie. Już po wykonaniu tego opracowania w gminie Pleszew oszacowano liczbę pracujących na 13,8 tys., w tym w mieście na 9,1 tys. (Śleszyński, Wiedermann 2020).

W przypadku Pleszewa dość dużą rolę odgrywają dojazdy do pracy. Odejmując zatrudnienie w rolnictwie, okazuje się, że mniej więcej co piąty pracujący przyjeżdżał spoza gminy. Dostępna statystyka GUS za 2011 r. wskazuje bowiem, że do gminy przyjeżdżało 1,5 tys. osób, a wyjeżdżało z niej 1,0 tys. osób. Główne kierunki przyjazdów to m.in. Gołuchów (275 osób), Dobrzyca (254), Czermin (248) i Chocz (231), a wyjazdów - Poznań (249) i Kalisz (149).

Można zatem jeszcze wnioskować o stosunkowo zrównoważonej strukturze dojazdów, przy czym szczególnie pozytywny jest fakt, że gmina jest znaczącym ośrodkiem koncentracji miejsc pracy. Z punktu widzenia rozwoju demograficznego może to być zachęcający czynnik dla atrakcyjności osiedleńczej. 
Przesłanką rozwoju gospodarczego jest też aktualna struktura ekonomiczna zarejestrowanych przedsiębiorstw. Według rejestru REGON, w końcu 2017 r. w gminie było zarejestrowanych 3188 podmiotów gospodarczych, z czego w 32 podmiotach liczba pracujących przekraczała 49 osób (w tym w 3 powyżej 249 pracujących; jeden z nich na Liście 500 dziennika „Rzeczpospolita”). Ponadto w tym samym czasie było zarejestrowanych 14 spółek z udziałem kapitału zagranicznego. Jednak wartości te w odniesieniu zwłaszcza do sektora najmniejszych podmiotów są znacznie przeszacowane

Stosunkowo duża liczba miejsc pracy jest pozytywną okolicznością, jeśli chodzi o atrakcyjność migracyjną. Stwarza to też przesłanki do zajmowania przez Pleszew w przyszłości wyższej lub tej samej pozycji w systemie osadniczym niż aktualnie, szczególnie w związku z reorganizacją sieci osadniczej, którą wymusi depopulacja i postarzanie się struktury wieku w całym kraju i prawdopodobne „wypadanie” części miast z dotychczasowych funkcji powiatowych. Sprzyjać temu będzie stosunkowo wysoki kapitał społeczny miasta. W badaniach Koneckiej-Szydłowskiej i Dominiak (2012) Pleszew wśród innych małych miast (poniżej 20 tys. mieszkańców) sklasyfikowano w najlepszej pod tym względem kategorii (wraz z Murowaną Gośliną, Słupcą, Ostrzeszowem, Obornikami, Nowym Tomyślem, Wolsztynem, Kępnem i Mosiną).

\section{Uwarunkowania planistyczne}

Podstawową przesłanką planistyczną jest bezpośrednia podaż gruntów budowlanych i chłonność (pojemność) demograficzna w obowiązujących dokumentach gminy (studium uikzp, plany miejscowe). Przy tym zdecydowanie "twardsze” dane dotyczą planów miejscowych, które są wiążącym aktem prawa miejscowego, a studium jest jedynie przesłanką, którą należy kierować się przy wydawaniu decyzji lokalizacyjnych na obszarach bez planu miejscowego.

Według dostępnych danych (dane GUS/Ministerstwa Infrastruktury i Budownictwa, dotyczące sytuacji planistycznej w kraju, analizowane w corocznych raportach Instytutu Geografii i Przestrzennego Zagospodarowania PAN), na koniec 2016 r. w gminie było 27 obowiązujących planów miejscowych, w tym 13 uchwalonych na podstawie ustawy z $2003 \mathrm{r}$. Obejmowały one powierzchnię 876 ha, czyli nieco poniżej $5 \%$ powierzchni gminy. Plany te uchwalono w dużej części w celu zmiany przeznaczenia gruntów na użytkowanie nierolnicze (tzw. odrolnienia) - 483 ha.

Niewielki procent pokrycia planistycznego gminy nie upoważnia do wyciągania dalej idących wniosków na temat możliwych inwestycji i obliczenia tzw. chłonności demograficznej. Niemniej warto zwrócić uwagę na stosunkowo dużą wartość odrolnień, które obejmowały 2,7\% powierzchni gminy. Gdyby zakładać, że tylko połowa tych terenów zostanie przeznaczona pod zabudowę jednorodzinną, przyjmując wskaźnik zaludnienia 25 osób/ha, daje to miejsce dla 6,0 tys. osób, czyli $1 / 5$ aktualnej populacji gminy. $Z$ drugiej strony wiadomo też, że $27 \%$ powierzchni planów miejscowych jest przeznaczone pod zabudowę mieszkaniową (w tym $2 \%$ pod budownictwo wielorodzinne), co daje porównywalną wartość 
6,3 tys. osób (nie wiadomo jednak, w jakiej części plany obejmują już istniejąca zabudowę).

Według studium uwarunkowań i kierunków zagospodarowania przestrzennego gminy (z 2011 r.) zabudowa mieszkaniowa była dopuszczalna dla 13\% powierzchni gminy. Gdyby przyjąć wskaźnik taki jak w planach miejscowych (25 osób/ha w zabudowie jednorodzinnej), dałoby to chłonność na poziomie 58 tys. mieszkańców, a więc niemal dwukrotnie więcej, niż wynosi aktualna populacja. W świetle danych z innych gmin, w których przeszacowanie jest nawet 5i 10-krotnie większe, politykę przestrzenną gminy należy uznać za zadowalającą. Ponadto z powodu braku planów w roku 2016 wydano 191 decyzji lokalizacyjnych, w tym 28 o ustanowieniu lokalizacji inwestycji celu publicznego i $81 \mathrm{tzw}$. WZ (o warunkach zabudowy) dla budownictwa jednorodzinnego.

Gmina jest zatem słabo wyposażona w plany miejscowe, a zabudowę na podstawie decyzji o warunkach zabudowy realizuje się bardzo często. Łącznie w latach 2003-2016 wydano w gminie aż 2371 decyzji o warunkach zabudowy, podczas gdy w tym okresie oddano do użytku około 1,4 tys. mieszkań.

Podsumowując, przewidziana $\mathrm{w}$ dokumentach planistycznych chłonność demograficzna w wysokości około 6 tys. osób (głównie nowe tereny inwestycyjne z tzw. odrolnień) oraz zapisana w studium gminnym z 2011 r. (58 tys. mieszkańców) jest $\mathrm{w}$ pełni wystarczająca $\mathrm{z}$ punktu widzenia spodziewanych procesów demograficznych, przy czym w przypadku studium gminnego zaleca się rozważenie obniżenia powierzchni obszarów z dopuszczalną możliwością inwestycji mieszkaniowych, tj. terenów o funkcjach mieszkaniowych i mieszkaniowo-usługowych (zwłaszcza tych spośród MU, na których dopuszczalna zabudowa mieszkaniowa przekracza $40 \%$ - o ile takie tereny w mpzp istnieja).

\section{Założenia szczegółowe prognozy}

Biorąc pod uwagę zwłaszcza czynniki demograficzne, zdecydowano, że należy wykonać dwie wariantowe projekcje rozwoju demograficznego:

- wariant minimalny, związany z kontynuacją dotychczasowych niekorzystnych dla rozwoju gminy procesów demograficznych, zakładający postarzanie się struktury wieku, spadek dzietności, znaczne osłabienie napływu i niewielkie zwiększenie odpływu migracyjnego;

- wariant maksymalny, związany z utrzymaniem stosunkowo wysokiej stopy urodzeń na dotychczasowym poziomie, wynikającej z możliwego zwiększenia atrakcyjności migracyjnej wskutek inwestycji w miejsca pracy i utrzymania się napływu migracyjnego, pomimo silnego spadku zasobów migracyjnych.

Prognozy wykonano w perspektywie 2050 r. dla 3-letnich (2017-2020) oraz 5-letnich przedziałów czasowych (2025, 2030, 2035, 2045, 2050). Zastosowano prognozowanie demograficzne w podziale na 18 kategorii wieku (do 84 lat co 5 lat, 85 lat i więcej). Szczegółowe założenia prognostyczne przedstawiono w tabeli 2, a cząstkowe założenia dotyczące zdarzeń demograficznych także na rycinach. Punktem wyjścia do wszystkich szacunków były ustalenia związane z oszacowaniem liczby i rozmieszczenia stanów demograficznych na rok 2017. 
Tabela 2. Założenia do wariantowych prognoz dla gminy Pleszew w latach 2017-2050

\begin{tabular}{lll}
\hline \multicolumn{1}{c}{ Wskaźnik } & \multicolumn{1}{c}{ Wariant minimalny (A) } & \multicolumn{1}{c}{ Wariant maksymalny (B) } \\
\hline $\begin{array}{c}\text { Stan wyjścio- } \\
\text { wy prognozy } \\
(2017)\end{array}$ & \multicolumn{1}{c}{ Przyjęty według danych z rejestracji bieżácej, pomniejszony o 2\%, z czego 67\% } \\
przypadło na ludność w wieku 20-39 lat.
\end{tabular}

Źródło: opracowanie własne.

\section{Oszacowanie stanu wyjściowego prognozy}

Ostatnie dane na temat liczby i struktury demograficznej są dostępne (lipiec 2018 r.) za rok 2017. Następnie dla tych danych odjęto przeszacowaną ludność zameldowaną, a pozostającą $\mathrm{W}$ rzeczywistym miejscu zamieszkania poza granicami gminy, w tym za granicą. Przyjęto najbardziej realny poziom $2 \%$ populacji, który rozszacowano na 4 kategorie wieku według znanej struktury niezgodności adresów zameldowania i korespondencji/zamieszkania (Śleszyński 2011): wiek przedprodukcyjny $(4,0 \%)$, wiek produkcyjny mobilny $(67,0 \%)$, wiek produkcyjny niemobilny $(23,0 \%)$, wiek poprodukcyjny $(6,0 \%)$. Wyniki obliczeń przedstawiono w tabeli 3. Wyjściową liczbę ludności w 2017 r. oszacowano na 23807 osób. 


\section{Oszacowanie zdarzeń cząstkowych}

Oszacowanie poziomu urodzeń, zgonów, napływu i odpływu (ryc. 3) wykonano zgodnie z założeniami opisanymi $\mathrm{w}$ tabeli 3 . Wyniki przedstawiono $\mathrm{w}$ formie tabelarycznej i graficznej dla dwóch wariantów projekcyjnych.

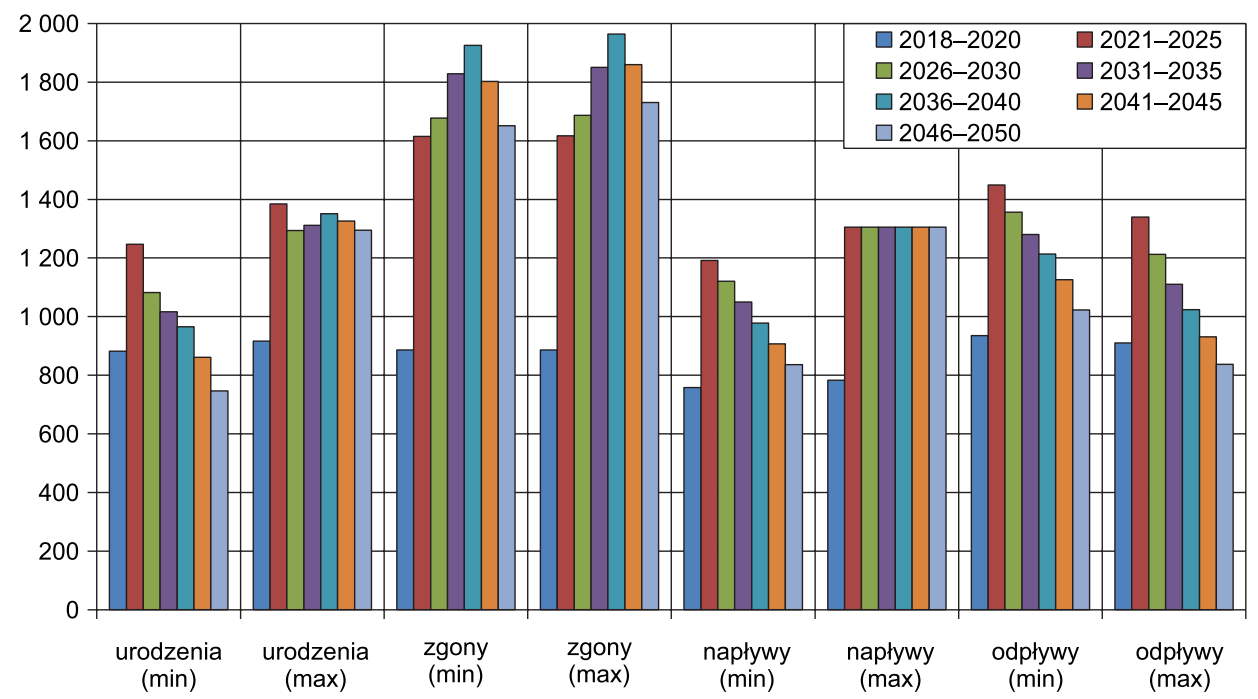

Ryc. 3. Założenia cząstkowe do prognozy demograficznej gminy Pleszew w latach 2018$2050 \mathrm{w}$ dwóch wariantach projekcyjnych

Źródło: opracowanie własne.

Tabela 3. Oszacowanie stanu wyjściowego prognozy dla gminy Pleszew

\begin{tabular}{|c|c|c|c|c|}
\hline \multirow{2}{*}{ Zmienna } & \multirow{2}{*}{$\begin{array}{l}\text { Liczba lud- } \\
\text { ności } \\
2017 \text { (GUS) }\end{array}$} & \multicolumn{2}{|c|}{$\begin{array}{l}\text { Przeszacowanie ludno- } \\
\text { ści zameldowanej }\end{array}$} & \multirow{2}{*}{$\begin{array}{l}\text { Liczba ludności } \\
\text { po przeszacowa- } \\
\text { niu (2017) }\end{array}$} \\
\hline & & $\%$ & liczba & \\
\hline Liczba ludności ogółem & 30026 & 1,9 & -568 & 29458 \\
\hline Liczba ludności w wieku 0-17 lat & 5582 & $-0,4$ & -24 & 5558 \\
\hline Liczba ludności w wieku 18-39 lat & 11544 & $-3,5$ & -402 & 11142 \\
\hline Liczba ludności w wieku 40-64 lat & 6727 & $-2,1$ & -138 & 6589 \\
\hline Liczba ludności w wieku 65 lat i więcej lat & 6173 & $-0,6$ & -4 & 6169 \\
\hline
\end{tabular}

Źródło: opracowanie własne.

W wariancie minimalnym przewiduje się systematyczny spadek urodzeń, wzrost zgonów (z kulminacją w latach 2036-2040) oraz spadek napływów i odpływów migracyjnych. Ujemne saldo ruchu naturalnego będzie charakterystyczne dla całego okresu prognozy i będzie się powiększać do poziomu około -900 osób w ostatnim pięcioleciu (2046-2050), a saldo ruchu wędrówkowego - będzie oscylować w granicach -170-260 osób na pięciolecie. Będzie ono najbardziej zależało od aktualnej liczby osób w wieku produkcyjnym mobilnym. W rezultacie liczba 
ludności będzie spadała w coraz większym tempie, a od około 2035 r. ujemne saldo rzeczywiste ustabilizuje się na poziomie -200-250 osób rocznie. Łączny spadek do 2050 r. wyniesie $-6,1$ tys. osób, czyli około $20 \%$ aktualnego stanu.

W wariancie maksymalnym są przewidywane większe fluktuacje, związane $z$ różnicowaniem się struktury wieku i wpływem tego na zdarzenia cząstkowe. Dotyczyć to będzie zwłaszcza poziomu urodzeń, którego wzrost nie będzie niestety kompensował liczby zgonów. Natomiast dodatnie będzie saldo ruchu migracyjnego, ale też nie zrównoważy ubytku naturalnego. W założeniach tego wariantu liczba ludności spadnie do 2050 r. o 1,5 tys. osób.

W obydwu projekcjach ujawniają się dwa podstawowe uwarunkowania dla rozwoju ludnościowego gminy Pleszew: starzenie się społeczeństwa, powodujące wzrost zgonów, oraz kurczenie się zasobów migracyjnych, które dla utrzymania dotychczasowego poziomu będzie wymagało wzrostu atrakcyjności miasta jako miejsca zamieszkania.

\section{Wyniki prognozy}

Zsumowanie zdarzeń cząstkowych daje w efekcie wyniki końcowe prognozy (tab. 4, ryc. 4). Przedstawiono je w formie tabelarycznej i graficznej dla dwóch wariantów projekcyjnych. Według obliczeń, prognozowana liczba ludności w 2050 r. może się wahać pomiędzy 23,3 a 28,0 tys. mieszkańców. Dodatkowo dla celów porównawczych na wykresie naniesiono projekcję GUS wykonaną dla gminy na lata 2017-2030 (GUS 2017).

Tabela 4. Wyniki prognozy demograficznej dla gminy Pleszew w latach 2017-2050 w dwóch wariantach projekcyjnych

\begin{tabular}{cccc}
\hline \multirow{2}{*}{ Rok } & \multicolumn{2}{c}{ Wariant } & \multirow{2}{*}{$\begin{array}{c}\text { Różnica między } \\
\text { wariantami }\end{array}$} \\
\cline { 2 - 3 } & minimalny & maksymalny & 0 \\
2017 & 29458 & 29458 & 86 \\
2020 & 29277 & 29363 & 444 \\
2025 & 28652 & 29096 & 974 \\
2030 & 27822 & 28796 & 1674 \\
2035 & 26779 & 28453 & 2539 \\
2040 & 25583 & 28122 & 3540 \\
2045 & 24422 & 27962 & 4663 \\
2050 & 23332 & 27995 & \\
\hline
\end{tabular}

Źródło: opracowanie własne.

Oprócz zmian ilościowych spodziewane są poważne zmiany jakościowe. W obydwu wariantach silnie wzrośnie liczba ludności w wieku poprodukcyjnym, przy czym w wariancie minimalnym oznacza to dojście do poziomu blisko $40 \%$ populacji (tab. 5). Najbardziej zagrożona postarzaniem się struktury wieku jest najstarsza, centralna część miasta. W wariancie minimalnym można też przewidywać, że w roku 2050 najmłodsza populacja spadnie do poziomu zaledwie 58\% stanu z 2017 r., a średnia (wiek produkcyjny) - osiągnie 60\% tego 


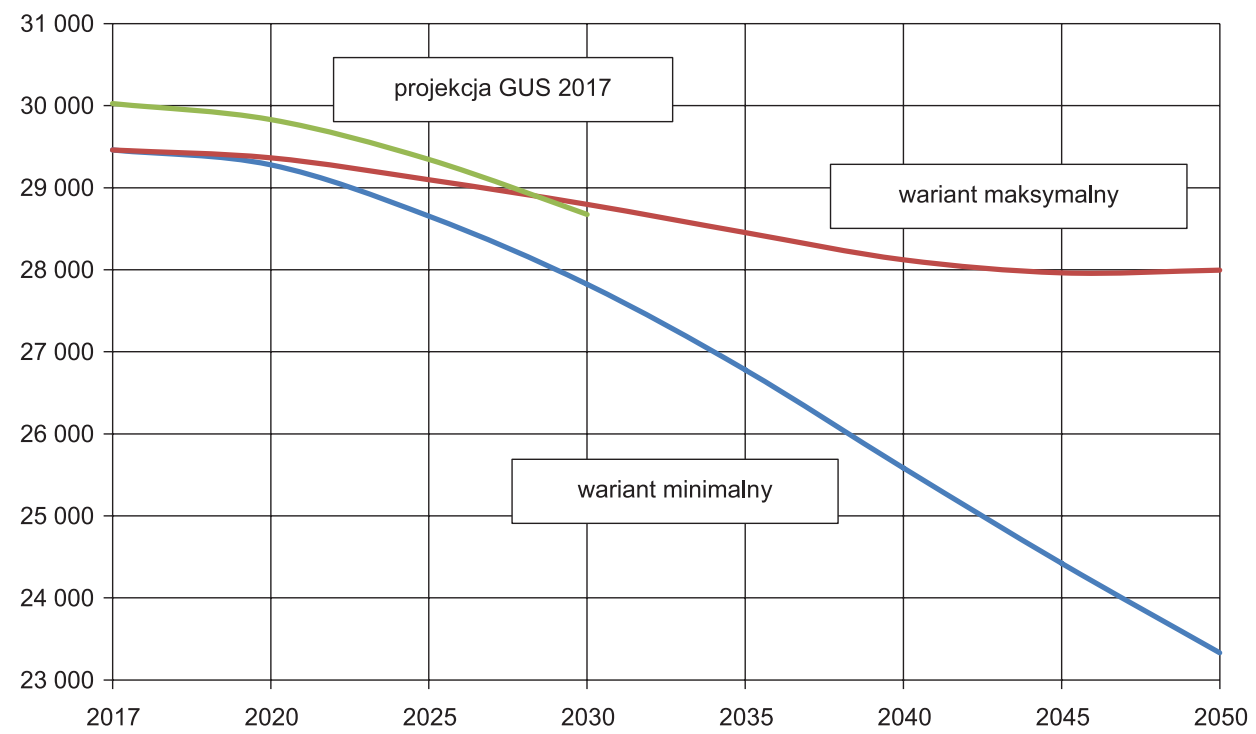

Ryc. 4. Wyniki projekcji demograficznych dla gminy Pleszew w latach 2017-2050 Źródło: opracowanie własne.

Tabela 5. Prognozowane zmiany w strukturze wieku w gminie Pleszew w latach 2017-2050

\begin{tabular}{|c|c|c|c|c|c|c|}
\hline \multirow[b]{2}{*}{ Rok } & \multicolumn{3}{|c|}{ Wariant minimalny } & \multicolumn{3}{|c|}{ Wariant maksymalny } \\
\hline & $\begin{array}{l}\text { wiek przed- } \\
\text { produkcyjny } \\
\text { (0-19 lat) }\end{array}$ & $\begin{array}{l}\text { wiek pro- } \\
\text { dukcyjny } \\
\text { (20-59 lat) }\end{array}$ & $\begin{array}{c}\text { wiek popro- } \\
\text { dukcyjny } \\
(60 \text { i więcej } \\
\text { lat) }\end{array}$ & $\begin{array}{l}\text { wiek przed- } \\
\text { produkcyjny } \\
\text { (0-19 lat) }\end{array}$ & $\begin{array}{l}\text { wiek pro- } \\
\text { dukcyjny } \\
\text { (20-59 lat) }\end{array}$ & $\begin{array}{c}\text { wiek popro- } \\
\text { dukcyjny } \\
\text { (60 i więcej } \\
\text { lat) }\end{array}$ \\
\hline 2017 & 6064 & 16341 & 7053 & 6064 & 16341 & 7053 \\
\hline 2020 & 5460 & 15554 & 8005 & 5504 & 15589 & 8011 \\
\hline 2025 & 5178 & 14915 & 8160 & 5404 & 15094 & 8194 \\
\hline 2030 & 4636 & 14265 & 8381 & 5122 & 14662 & 8462 \\
\hline 2035 & 4218 & 13180 & 8657 & 5037 & 13863 & 8806 \\
\hline 2040 & 4220 & 11665 & 8692 & 5425 & 12717 & 8937 \\
\hline 2045 & 3855 & 10584 & 8671 & 5416 & 12130 & 9047 \\
\hline 2050 & 3521 & 9715 & 8485 & 5448 & 11822 & 9030 \\
\hline $\begin{array}{c}2017-2050 \\
(2017=100)\end{array}$ & 58,1 & 59,5 & 120,3 & 89,8 & 72,3 & 128,0 \\
\hline $2017(\%)$ & 20,6 & 55,5 & 23,9 & 20,6 & 55,5 & 23,9 \\
\hline $2050(\%)$ & 16,2 & 44,7 & 39,1 & 20,7 & 44,9 & 34,3 \\
\hline $\begin{array}{c}\text { Zmiana } \\
\text { w pkt proc. }\end{array}$ & $-4,4$ & $-10,7$ & 15,1 & 0,1 & $-10,5$ & 10,4 \\
\hline
\end{tabular}

Źródło: opracowanie własne.

stanu. W wariancie maksymalnym zmiany są znacznie korzystniejsze, choć też negatywne: w 2050 r. spadnie liczba osób populacji przedprodukcyjnej (do 90\% stanu z 2017 r.) i produkcyjnej (72\%), a wzrośnie liczba osób w wieku poprodukcyjnym (128\%). 


\section{Ocena potrzeb terenów mieszkaniowych}

W gminie Pleszew chłonność (pojemność) demograficzną według studium uwarunkowań i kierunków zagospodarowania przestrzennego oszacowano na 58 tys. osób (Śleszyński i in. 2017), a projekcje liczby ludności wahają się maksymalnie do 28 tys. osób. $Z$ kolei nowe tereny inwestycyjne oszacowano w tym względzie na 6-6,3 tys. osób, przy łącznym napływie do 2050 r. w wysokości 8,6 tys. osób. Jednak tylko część tych nowych mieszkańców będzie potrzebowała nowych domów lub mieszkań, zdecydowanie większa część zajmie zagospodarowane już działki i ewentualnie bloki mieszkalne.

$\mathrm{Z}$ drugiej strony, $\mathrm{w}$ sensie zwiększonego zapotrzebowania, ujawnią się takie uwarunkowania, jak zagęszczenie zabudowy w najstarszej części miasta Pleszewa, w tym spadek atrakcyjności bloków wielorodzinnych, przy ich dekapitalizacji. Skutkować to powinno tendencją do rozgęszczania zabudowy. W odwrotny sposób teoretycznie powinno oddziaływać zmniejszanie się przeciętnej wielkości gospodarstwa domowego, związane ze starzeniem się populacji z powodu znacznie dłuższej średniej życia kobiet i zbliżające się w kierunku jedności (jednoosobowe gospodarstwa domowe). To ostatnie może być jednak również przyczyną zwiększonej podaży działek zabudowanych.

Wydaje się, że ważniejsze będą jednak czynniki związane z rozgęszczaniem zabudowy i dążeniem do poprawy warunków życia w postaci zwiększonego popytu na domy jednorodzinne. Natomiast zmniejszone zapotrzebowanie na powierzchnię może wystąpić w zasadzie tylko tam, gdzie zabudowa jednorodzinna zlokalizowana jest na dużych działkach. $Z$ powodu istniejących rezerw terenowych nie oznacza to w sumie powiększania terenów inwestycyjnych.

Biorąc pod uwagę powyższe uwarunkowania, zaleca się w perspektywie roku 2050 zmniejszenie podaży terenów mieszkaniowych w studium uikzp o 20-30\% oraz utrzymanie (niepowiększanie) rezerw inwestycyjnych $\mathrm{w}$ postaci gruntów odrolnionych na cele mieszkaniowe (483 ha).

\section{Wnioski dla polityki przestrzennej}

Analizy pozwalają na sformułowanie następujących wniosków praktycznych:

1. W gminie Pleszew w perspektywie najbliższych dekad należy spodziewać się dość wyraźnego spadku liczby ludności. Liczba mieszkańców wraz z populacją niezameldowaną $\mathrm{w}$ roku 2050 powinna się mieścić $\mathrm{w}$ granicach 23,3 tys. (wariant minimalny) do 28,0 tys. (wariant maksymalny).

2. W wariancie minimalnym spodziewany jest systematyczny spadek liczby ludności, zaś w wariancie maksymalnym najpierw nastąpi spadek, a potem, od około 2040 r., stabilizacja. Wynikać to będzie z założonego „zasilenia” napływem ludności $\mathrm{w}$ wieku produkcyjnym mobilnym i tym samym podtrzymania stosunkowo wysokiej, jak na ten region kraju, stopy urodzeń. 
3. Na zmiany ludnościowe $\mathrm{w}$ całym okresie 2017-2050 w największym stopniu wpłyną zgony (11,4-11,6 tys. w obydwu wariantach) i odpływy (7,4-8,4 tys.), a w nieco mniejszym urodzenia (6,8-8,9 tys.) i napływy $(6,8-8,6$ tys.).

4. Nastąpi silne postarzenie się struktury wieku, do poziomu 34-39\% udziału wieku poprodukcyjnego (60 lat i więcej) w populacji. Wystąpi zjawisko tzw. podwójnego starzenia się, bowiem w tej grupie podwoi się liczba „osiemdziesięciolatków”. Wymagać to będzie większej dbałości o politykę przestrzenną i planowanie infrastruktury, zwłaszcza pod kątem efektywności, związanej z potrzebami osób starszych.

5. W związku z prognozowanymi trendami demograficznymi w gminie występuje pewne przeszacowanie terenów pod zabudowę mieszkaniową w studium uikzp (zaleca się obniżkę tego typu terenów o 20-30\%).

6. Wskazane jest przygotowanie bardziej szczegółowego opracowania w tym zakresie, dotyczącego inwentaryzacji istniejącej zabudowy oraz waloryzacji potencjalnych terenów inwestycyjno-mieszkaniowych w granicach administracyjnych miasta i jego bezpośrednim sąsiedztwie (strefa podmiejska), a także monitoring miejscowości wiejskich narażonych na największe postarzenie się struktury wieku i wyludnianie się.

7. Kluczowe znaczenie dla utrzymania potencjału demograficznego miasta w przyszłości będzie miał napływ ludności, stąd działania samorządu powinny być nakierowane zwłaszcza na tworzenie atrakcyjnych miejsc pracy i podnoszenia warunków zamieszkania (jakości życia). Dużą szansą w tym zakresie mogłyby być zachęty dla ludności wiejskiej w otoczeniu (powiat pleszewski) do przenoszenia się do Pleszewa lub w jego pobliże, co jest uzasadnione stosunkowo niskim poziomem urbanizacji w regionie. Tego typu działania powinny być przedmiotem rozwiązań polityki regionalnej, społecznej i mieszkaniowej państwa, np. krajowego planu restrukturyzacji sieci osadniczej.

\section{Podziękowania}

Autor składa podziękowania Urzędowi Miasta i Gminy Pleszew za sfinansowanie badań i możliwość opublikowania ekspertyzy w celu jej upowszechnienia.

\section{Literatura}

Bąkowska E., Kaczmarek T., Walaszek M. 2016. Lokalne prognozy demograficzne jako podstawa planowania sieci szkolnej - przykład gmin Tarnowo Podgórne i Rokietnica w aglomeracji poznańskiej. Rozwój Regionalny i Polityka Regionalna.

Bul R., Kaczmarek T. 2016. Rola Poznania jako ośrodka metropolitalnego i jego powiązania w województwie wielkopolskim. Rozwój Regionalny i Polityka Regionalna, 36: 73-89.

Churski P. 2012. Zróżnicowanie poziomu rozwoju społeczno-gospodarczego województwa wielkopolskiego w układzie gmin w 2007 r. Rozwój Regionalny i Polityka Regionalna, 19: 56-98.

Czyż T., Perdał R. 2016. Region wielkopolski na ścieżce rozwoju społeczno-gospodarczego w latach 2000-2014. Rozwój Regionalny i Polityka Regionalna, 36: 9-26. 
Dolata M. 2009. Wewnętrzne zróżnicowanie poziomu rozwoju gospodarczego województwa wielkopolskiego. [W:] T. Czyż (red.), Charakter regionalny województwa wielkopolskiego. Rozwój Regionalny i Polityka Regionalna, 9: 63-76.

Dominiak J., Konecka-Szydłowska B. 2014. Wpływ kryzysu na sytuację społeczno-gospodarczą gospodarstw domowych. Przykład Wielkopolski. Rozwój Regionalny i Polityka Regionalna, 25: 89-111.

Fogel P. 2012. Wskaźniki oceny polityki i gospodarki przestrzennej w gminach. Biuletyn KPZK PAN, 250.

Gibas P., Heffner K. 2018. Społeczne i ekonomiczne koszty bezładu przestrzeni - osadnictwo obszarów wiejskich. [W:] A. Kowalewski, T. Markowski, P. Śleszyński (red.), Koszty chaosu przestrzennego. Studia KPZK PAN, 182, 2: 163-195.

Górecka S., Szmytkie R., Maleszka W. 2016. Prognoza demograficzna dla obszarów wiejskich województwa dolnośląskiego do 2020 r. Studia Obszarów Wiejskich, 41: 199-207.

GUS 2017. Prognoza ludności gmin na lata 2017-2030 (opracowanie eksperymentalne). Główny Urząd Statystyczny, Departament Badań Demograficznych i Rynku Pracy, Warszawa.

Hauke J., Konecka-Szydłowska B. 2011. Nierówności wewnątrzregionalne w województwie wielkopolskim. Studium małych miast. Rozwój Regionalny i Polityka Regionalna, 16: 87-98.

Jarczewski A. 2015. Metoda demograficzna dla samorządu. Studia Ekonomiczne UE w Katowicach, 223: 84-93.

Jończy R. 2014. Problem nierejestrowanej emigracji definitywnej (emigracji zawieszonej) w badaniu procesów społeczno-gospodarczych na obszarach wiejskich. Prace Naukowe UE, Wrocław, 360: 11-18.

Kołodziejczak A. 2007. Uwarunkowania funkcjonalno-przestrzenne rozwoju małych miast Wielkopolski. [W:] E. Rydz (red.), Podstawy i perspektywy rozwoju małych miast. Wyd. Akademii Pomorskiej w Słupsku, s. 85-94.

Konecka-Szydłowska B. 2018. Rozwój małych miast powiatowych województwa wielkopolskiego w ujęciu koncepcji urban resilience. Space-Society-Economy, 24: 27-44.

Konecka-Szydłowska B., Maćkowiak H. 2014. Spatial differences in the level of population and settlement development in Wielkopolskie voivodship. Bulletin of Geography. Socio-economic Series, 24: 93-104.

Konecka-Szydłowska B., Maćkowiak H. 2016. Zróżnicowanie funkcjonalne miast województwa wielkopolskiego. Rozwój Regionalny i Polityka Regionalna, 36: 41-59.

Kowalewski A., Markowski T., Śleszyński P. (red.) 2018. Studia nad chaosem przestrzennym. Studia KPZK PAN, 182(1-3).

Krysiński D. 2013. Społeczne bariery rozwoju postwojewódzkich ośrodków regionalnych jako zagrożenie dla polityki rozwojowej Polski. Przykład Kalisza. Rozwój Regionalny i Polityka Regionalna, 23: 5-20.

Męczyński M., Konecka-Szydłowska B., Gadziński J. 2010. Poziom rozwoju społeczno-gospodarczego i klasyfikacja małych miast Wielkopolski. Ekspertyza na zlecenie Urzędu Marszałkowskiego w Poznaniu, Uniwersytet im. Adama Mickiewicza w Poznaniu, Instytut Geografii Społeczno-Ekonomicznej i Gospodarki Przestrzennej, Poznań. Maszynopis.

Paradysz J. 2012. Prognoza demograficzna dla Poznania i powiatu poznańskiego do 2035 roku. Zeszyty Naukowe UE w Poznaniu, 245: 37-54.

Parysek J.J. 2016. Asking about the future of spatial management in Poland (thirteen years on from the 2003 legal regulation). Ruch Prawniczy, Ekonomiczny i Socjologiczny, 78, 2: 37-58.

Podemski K., Przestalski A. (red.) 2015. Społeczność Pleszewa. Kapitał społeczny, pamięć zbiorowa i komunikowanie publiczne. Poznańskie Towarzystwo Przyjaciół Nauk, Poznań.

Śleszyński P. 2011. Oszacowanie rzeczywistej liczby ludności gmin województwa mazowieckiego z wykorzystaniem danych ZUS. Studia Demograficzne, 2: 35-57.

Śleszyński P. 2017. Wyznaczenie i typologia miast średnich tracących funkcje społeczno-gospodarcze. Przegląd Geograficzny, 89, 4: 565-593.

Śleszyński P. 2018. Prognozowanie procesów demograficznych na potrzeby planowania przestrzennego. Przypadek gminy Konstancin-Jeziorna, Mazowsze. Studia Regionalne, 25: 13-27.

Śleszyński P., Komornicki T. 2016. Klasyfikacja funkcjonalna gmin Polski na potrzeby monitoringu planowania przestrzennego. Przegląd Geograficzny, 88, 4: 469-488.

Śleszyński P., Wiedermann K. 2020. Próba szacunku liczby i struktury pracujących oraz bazy ekonomicznej miast w Polsce. Prace Komisji Geografii Przemysłu PTG (w druku).

Zborowski A. 2001. Prognoza demograficzna dla Krakowa: metoda badań. [W:] B. Kortus (red.), Człowiek i przestrzeń. Profesorowi Adamowi Jelonkowi w 70. rocznicę urodzin. Instytut Geografii i Gospodarki Przestrzennej UJ, Kraków, s. 89-97. 


\title{
Current and expected demographic processes in the Pleszew commune and their importance for spatial policy
}

\begin{abstract}
The study is a short compilation of an expertise prepared for Pleszew local authorities. Its aim was, among other things, an alternative population forecast based on alternative methods of population estimation, made for the needs of spatial planning and development of the city and the municipality. For the purposes of the forecast, the initial number of inhabitants was first corrected. Next, assumptions were formulated for two variants (development scenarios). In the projections, the cohort-component method was used, calculating births, deaths, inflows and outflows for the following time ranges (2017-2020 and then 65 years to 2050). In the perspective of the coming decades, a fairly pronounced decrease in population should be expected in the commune (to the level of 23.3-28.0 thousand) with a clear aging of the population. Then the results were confronted with the balance of areas for various functions in the study of land development conditions and directions, showing a certain surplus of investment areas. It was recommended that investment areas be reduced. It is advisable, inter alia, to prepare a more detailed study concerning the inventory of existing buildings and the valorisation of potential investment and residential areas within the administrative borders of the city and its immediate vicinity (the suburban zone), as well as to monitor rural localities exposed to the greatest age structure aging and depopulation. On the other hand, the inflow of population will be of key importance for maintaining the demographic potential of the city in the future, hence the activities of the self-government should be directed in particular at creating attractive jobs and improving living conditions (quality of life). Incentives for the rural population in the surroundings (Pleszew poviat) to move to Pleszew or its vicinity, which is justified by the relatively low level of urbanisation in the region, could be a great opportunity in this respect. Such measures should be the subject of regional, social and housing policy solutions of the state, e.g. the national plan for restructuring of the settlement network.
\end{abstract}

Key words: Demographic structure of population, internal migration, demographic forecast, spatial planning, demographic capacity and absorbency, Pleszew 